\title{
Penetrating Lung Injury Caused by a Close-range Blank Cartridge: Case Report
}

\section{Yakın Mesafeden Kurusıkı Merminin Neden Olduğu Penetran Akciğer Yaralanması: Olgu Sunumu}

\begin{abstract}
(D) Saniye Göknil Çalık1 1 , (D) Mustafa Çalık2 2 , (D) Mehmet Orku
1KTo Karatay University Vocational School of Health Services, Departm
2Konya Training and Research Hospital, Clinic of Thoracic Surgery, Kon
3Konya Training and Research Hospital, Clinic of Cardiovascular Surgery,
ABSTRACT
A 17-year-old male was brought to the emergency department
with chest injury by a gunshot from a blank cartridge (BC). No
bullet or fragment wasseen in the radiological examination. The
patient underwent left thoracotomy for hemopneumothorax.
Chest injuries due to BCs have rarely been reported in the
literature. The word "blank" gives people a false sense of safety.
Although BC ammunition does not contain any bullets or parts
coming out of the barrel, it can lead to serious injury or even
death, especially at contact or close-range.
\end{abstract}
Keywords: Blank cartridge, barrel, gas pressure, gas jet
ÖZ

On yedi yaşındaki erkek hasta sol göğsünden Kurusıkı (KS) silah yaralanması nedeniyle acil servise getirildi. Radyolojik incelemede mermi veya parçası görülmedi. Hastaya hemopnömotoraks nedeniyle sol torakotomi yapıldı. KS silahlara bağlı göğüs yaralanmaları nadiren literatürde bildirilmiștir. "kurusıkı" veya "boş" kelimesi, insanlara yanlıș bir güvenlik duygusu verir. KS mühimmat herhangi bir mermi çekirdeği veya namludan çıkan bir parça içermemesine rağmen özellikle temas veya yakın atış mesafesinde ciddi yaralanmalara hatta ölümlere bile yol açabilir.

Anahtar Kelimeler: Kurusıkı mermi, namlu, gaz basıncı, gaz jeti

\section{Introduction}

Blank cartridges (BCs) were originally designed and manufactured for the training purposes of the Prussian army. Today, these weapons or ammunition are used in military training maneuvers or funerals, pointing the start of races in starting pistols and in entertainment industries such as in historical re-enactments, theatre, and movie special effects. BC defines a particular type of ammunition that discharges sound and gas flares, but no bullet or shot (1). Contrary to their production purpose, BCs have become very popular in society and amongst criminals due to their low prices, being easily available, being easily transformed into firearms and their uncertain legal status. Therefore, morbidity and mortality due to BCs are increasing (2). Several cases have been presented in the literature since its was first described by Hamilton in 1865 (3). Herein, we present a rare case of penetrating lung injury due to a gunshot by a $\mathrm{BC}$ pistol.

\section{Case Report}

A 17-year-old male patient was brought to the emergency department with chest pain and shortness of breath due to the penetrating chest trauma from a gunshot injury. His physical examination on admission was as follows: conscious, cooperative oriented, BP: 97/66 mmHg, heart rate: $122 / \mathrm{min}$, body temperature: $37.4{ }^{\circ} \mathrm{C}$ and saturation: $91 \%$ with oxygen. Vital signs were consistent with hypovolemic shock. He was pale and somnolence. At first glance, there was a single circle entrance wound at the left $4^{\text {th }}$ intercostal space in the midclavicular line which was $32 \times 39$ $\mathrm{mm}$ in size and had clot and bleeding around without an exit wound. The wound was partially covered with soot. There was limited emphysema in the subcutaneous soft tissues extending from the left lateral chest wall to the right hemithorax (Figure 1A). The left lung was less involved in breathing and breathing sounds were less heard in the lower region of the left hemithorax. The chest X-ray and contrast-enhanced chest tomography (CT) demonstrated entrance wound over the $4^{\text {th }}$ intercostal space, irregularly shaped subcutaneous emphysema extending from the left lateral chest wall to the right hemithorax and left hemopneumothorax with a possible bullet trajectory from the upper lobe of the left lung to the lower superior lobe segment with hyperdense consolidation (Figure 1B, 1C and 1D). No bullet or fragment was seen in radiological 
examination. A left tube thoracostomy was performed at emergency room settings because of the hemopneumothorax. First, a huge air leak and approximately $650 \mathrm{~mL}$ of blood were drained after chest tube insertion. Therefore, he underwent left thoracotomy. During operation, no injury was observed in the ribs. It was seen that the gas jet passed through the thorax by lacerating the pectoral and intercostal muscles, and left lung was collapsed, and that the pleural cavity was filled with approximately $250 \mathrm{~mL}$ of blood (Figure 2). There were tissue losses in the lingular segment of the upper lobe (Figure 3 ) and the superior segment of the lower lobe in the form of a puncture mark of approximately $15 \mathrm{~mm}$. Anterior pericardium showed moderate hemorrhages, but there were no ruptures and bleeding. Wedge resection of the lingular segment of the upper lobe and the superior segment of the lower lobe was performed.

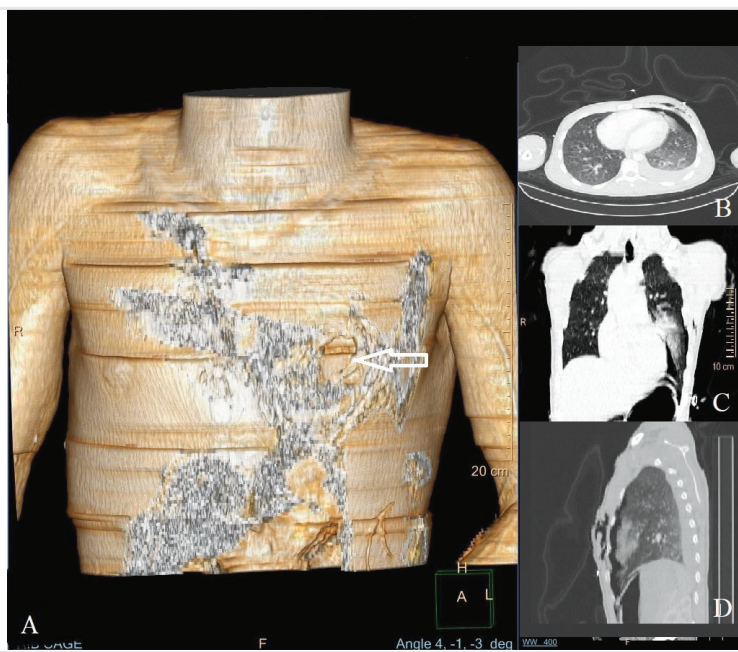

Figure 1 (A). The three-dimensional reconstruction image showed single entry wound in the left 4th intercostal space without an exit wound (white arrow) and subcutaneous emphysema extending from the left lateral chest wall to the right hemithorax (irregularly shaped black and white area); (B) Axial (C) Coronal and (D) Sagittal views of contrast-enhanced chest tomography demonstrated bullet entrance over the left $4^{\text {th }}$ intercostal space, subcutaneous emphysema with a possible bullet trajectory from the left lung upper lobe to the lower lobe superior segment with hyperdense consolidation

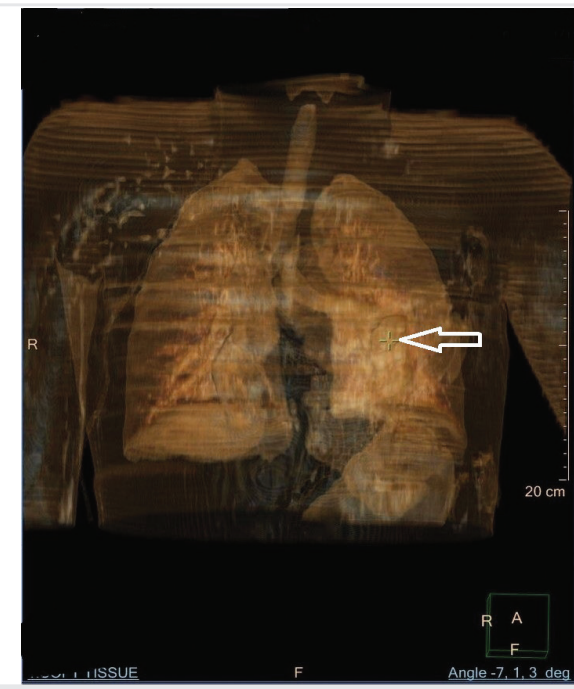

Figure 2. 3D reconstruction image of entry wound (white arrow) and hyperdense consolidation of the left lung
No additional organ injury was detected in the chest. He was followed up in the intensive care unit postoperatively and recovery was uneventful. He was discharged on the postoperative $9^{\text {th }}$ day without any complaints. Written informed consent was obtained from the patient for publishing the individual medical records.

\section{Discussion}

Ballistic is the branch of science that examines the movement of the bullet. The possession and use of conventional firearms throughout the world is determined by strict rules and monitored at the same rate. It is sad that this does not apply to BCs (4). For this reason, in most of the countries as well as in Turkey, BCs are often used for celebrations such as national days, weddings and military farewell parties and sports activities especially football and basketball games. BCs are generally not considered firearms and regarded as harmless or as toys. According to the law issued in 2008, anyone over the age of 18 can easily buy BC pistols if they are not punished for more than a year from opposition to Law No. 6136 on firearms and knives. The laws on weapons and knives also do not need administrative control and supervision by law enforcement officers $(1,4)$. Therefore, they are sold unlicensed or with few restrictions, and their use is poorly supervised. BC pistols, as required by law, cannot fire any bullet or fragments, and cannot include metal parts that can be removed by daily tools. However, with the replacement of barrel by criminals, they become capable of firing metal or plastic parts placed in the front part of the conventional bullet or cartridge. Under certain circumstances, even without making any changes, they can cause severe injuries and even deaths in their legal status (4). In the last 30 years, an increase in suicide, murder and accident rates has been reported. Deaths are mostly caused by head, neck, chest and substantial vessel injuries. Thoracic injuries are rare (5).

Bullets with a velocity more than $609.6 \mathrm{~m} / \mathrm{s}$ are called high-energy bullets, whereas those with a velocity less than $457.2 \mathrm{~m} / \mathrm{s}$ are called lowenergy bullets (6). From a ballistic aspect, BCs act as low-energy weapons, mostly in civilian use. The differential diagnosis between conventional ammunition and BC injury is very complex and almost impossible $(2,4,5)$. This was the case in our report. Initially, we thought it was a

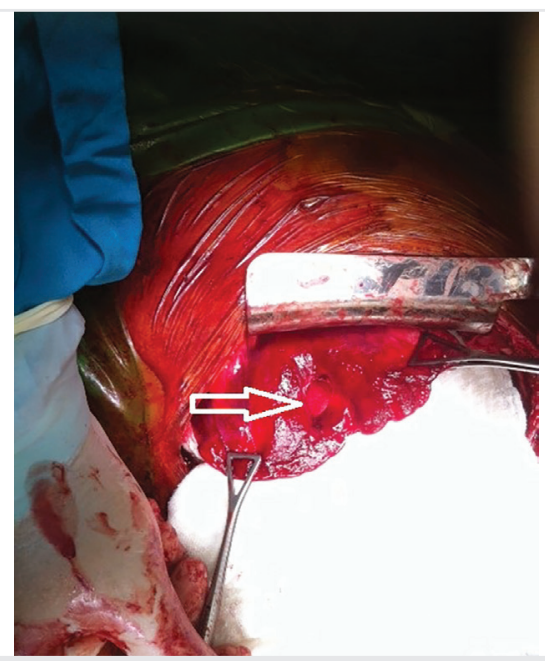

Figure 3. Tissue loss in the lingular segment of the upper lobe (white arrow) 
conventional gunshot wound. It was evaluated as BC injury regarding the absence of an exit wound and a bullet and the anamnesis. The types of damages are laceration, penetration, crushing/contusion and a temporary cavity for a shorter term. In BCs, tissue damage is caused by two primary mechanisms, consisting of gas jet-borne barotrauma that are induced by the striking wave of gunpowder explosion and thermal damage (6). A hyperdense contusion demonstrating bullet trajectory through the thorax to the in front of the pericardium was found in our case (Figure 2). Nevertheless, BCs are generally loaded with black powder or nitrocellulose that detonates rather than burns. Nitrocellulose combustion creates $2000-3000{ }^{\circ} \mathrm{C}$ heat in the barrel and $1500{ }^{\circ} \mathrm{C}$ at the tip, and thermal injury is caused by flame burn. As with other firearms, BC is available in several loads and caliber sizes. Its shot distance is reported to be $20 \mathrm{~cm}$ in the user manual. This depends on the type of BC, such as revolver or pistol and the length of the barrel and the caliber of the bullet. A $9 \mathrm{~mm}$ cartridge fired from a revolver handgun with a barrel length of $105 \mathrm{~mm}$ with a pressure wave at 1200 to $1500 \mathrm{~m} / \mathrm{s}$ will create $950 \mathrm{~mL} / \mathrm{g}$ gas pressure with nitrocellulose and $280 \mathrm{~mL} / \mathrm{g}$ with black powder. The pressure in the barrel drops to 200 bar and drops to 5, 3, and 1 bar at distances 3, 5 and $10 \mathrm{~cm}$ from the tip, respectively. The energy intensity represents the energy that $1 \mathrm{~cm}^{2}$ is exposed to, and can be equivalent to $0.75,0.27$ and $0.1 \mathrm{~J} / \mathrm{mm}^{2}$ at 0,5 and at $10 \mathrm{~cm}$, respectively. It reaches $0.1 \mathrm{~J} / \mathrm{mm}^{2}$, which is the required energy to penetrate the human skin, even at $10 \mathrm{~cm}$ away from the barrel. In a recent study performed using revolver and pistol with pigskin and ballistic gel, $9 \mathrm{~mm}$ bullets were fired, and the mechanical destruction was found to be between $22 \mathrm{~mm}$ to $61 \mathrm{~mm}$ with a mean of $40 \mathrm{~mm}$. When a $\mathrm{BC}$ is fired, the gas jet that emerges in an explosion in the barrel acts as a bullet at close or contact range. This pressure or invisible bullet can be powerful enough to penetrate the soft tissue and even bones $(2,5)$. Considering the skin defect and the entrance wound in our case, we think that a $9 \mathrm{~mm}$ cartridge was used, although we did not have any ballistic information because the criminal and gun could not be seized. We suppose that subcutaneous emphysema in the patient is due to close range or contact shot. BC should be considered as a common gunshot injury and surgical treatment should be offered if necessary. In spite of the injury leading to hemopneumothorax and lung injury, we believe that the reason why mortality was not observed was the fact that major vascular structures of the left lung were not affected.

\section{Conclusion}

Chest injuries due to BCs have rarely been reported in the literature. The word "blank" gives people a false sense of safety. It is evident that BCs are used for purposes other than production purpose. The prevention of criminal use of these weapons is in the hands of the lawmakers and manufacturers. Lawmakers should strictly supervise their registration, sales and use as equivalent to firearms. Manufacturers should use new substances that produce lower pressure instead of black powder or nitrocellulose flour in the cartridge. Although there are no bullets in the $\mathrm{BCs}$, precautions should be taken as deaths and serious injuries can occur if BCs are fired at very close distances.

Informed Consent: Written informed consent was obtained.

Peer-review: Externally peer-reviewed.

Author Contributions: Surgical and Medical Practices - S.G.C., M.C.. M.O.Ş., M.D., H.E.; Concept - S.G.Ç., M.C.., M.O.Ş., M.D., H.E.; Design S.G.C.., M.C.., M.O.S., M.D., H.E.; Data Collection and/or Processing - S.G.C.., M.C.., M.O.S., M.D., H.E.; Analysis and/ or Interpretation - S.G.C.., M.Ç., M.O.S., M.D., H.E.; Literature Search - S.G.Ç., M.Ç., M.O.Ş., M.D., H.E.; Writing Manuscript - S.G.Ç., M.Ç., M.O.S,., M.D., H.E.

Conflict of Interest: No conflict of interest was declared by the authors.

Financial Disclosure: The authors declared that this study received no financial support.

\section{References}

1. Gülșen I, Ak H, Sosuncu E, Bulut MD. Are blank cartridge guns really harmless? Ulus Travma Acil Cerrahi Derg 2014; 20: 214-6.

2. Pircher R, Große Perdekamp M, Thierauf-Emberger A, Kramer L, Pollak S., Geisenberger D. Wound morphology in contact shots from blank cartridge handguns: a study on composite models. Int J Legal Med 2017; 131: 1333-9.

3. Berlatzky Y, Katz S, Ayalon A, Abu-Dallo K. Abdominal injuries due to blank cartridges. Injury 1977; 9: 77-8.

4. Demirci S, Dogan KH, Koc S. Fatal injury by an unmodified blank pistol: a case report and review of the literature. J Forensic Leg Med 2011; 18: 237-41.

5. Große Perdekamp M, Glardon M, Kneubuehl BP, Bielefeld L, Nadjem H, Pollak $\mathrm{S}$, et al. Fatal contact shot to the chest caused by the gas jet from a muzzleloading pistol discharging only black powder and no bullet: a case study and experimental simulation of the wounding effect. Int J Legal Med 2015; 129: 125-31.

6. Çalık SG, Çalık M, Esme H. Air Guns: Would you buy these "Toys" for your children? İstanbul Med J 2018; 19: 180-2. 